\title{
Libraries in the Universities of the World
}

Dr. Eells recently returned from a twoand-a-half year trip around the world, following four years of service in Japan as Adviser on Higher Education.

$\mathrm{T}$

HE AVERAGE NUMBER of books reported in over I 500 university and college libraries throughout the world is slightly over I 38,ooo volumes. The largest average size of university libraries are found in Europe with an average of more than 260 ,ooo volumes; the smallest in the universities of South America with an average only one tenth as great, less than 26,000. Those of the United States are slightly below the world average, with 125 , 000 volumes per institution, although the world's two largest university libraries are found in the United States.

These figures are based upon data reported in the most recent and comprehen. sive reference volumes, Universities of the World Outside U.S.A. 1950 and American Universities and Colleges 1952, both published by the American Council on Education, Washington, D.C. The first named volume gives some information on 1959 foreign institutions of higher education in 85 countries. In many cases, however, this information is limited to the name and location of the institution and perhaps the names of one or two of its administrative officers. Reasonably complete "exhibits" are found for 855 institutions. ${ }^{1}$ Of these,

1 Of the total of 1959 no less than 717 are located in the Union of Soviet Socialist Republics. For none of these is a complete and adequate exhibit given although
666 , or $77 \%$, report the number of volumes in their libraries.

It should be noted, perhaps, that some institutions reported number of volumes in round numbers only, usually to the nearest I,OOO volumes, but occasionally to the nearest I0,000 or even I00,000 volumes. Among the 666 foreign institutions included in this study $65 \%$ reported thus in round numbers. In the case of the 900 institutions in the United States the similar percentage is 25. For the entire group of I 566 institutions it is 42 . It is believed, however, that such approximations make little or no difference for the analysis of this article which deals for the most part with totals and averages. More accurate reports might make slight changes in the relative ranks of the individual libraries listed in Table II, but the intention there is to indicate the general ranking of the major university libraries and their distribution by countries, not to fix the exact rank of each with complete statistical accuracy. This would require original data not only more nearly exact in statement but also in definition of the term "volumes." The figures given here are of course no better than the sources from which they have been taken, but the two reference works used are probably the best that have been produced with comparative and world

for a few of the larger institutions the number of volumes in the library is indicated in round numbers. Omitting the Soviet institutions, I $242^{2}$ remain. The analysis in this article disregards the Soviet university libraries except in Table II where the four largest are included. 
TABLE I

Summary of Libraries in Universities of the World

\begin{tabular}{|c|c|c|c|c|c|}
\hline Region & $\begin{array}{l}\text { Number of } \\
\text { Institutions } \\
\text { Having } \\
\text { Exhibits }\end{array}$ & $\begin{array}{l}\text { Number } \\
\text { Reporting } \\
\text { Volumes } \\
\text { in Library }\end{array}$ & $\begin{array}{l}\text { Percent } \\
\text { Reporting } \\
\text { Volumes } \\
\text { in Library }\end{array}$ & $\begin{array}{l}\text { Total } \\
\text { Volumes } \\
\text { Reported }\end{array}$ & $\begin{array}{c}\text { Average } \\
\text { Volumes Per } \\
\text { Reporting } \\
\text { Institution }\end{array}$ \\
\hline $\begin{array}{l}\text { Europe } \\
\text { United States } \\
\text { Asia } \\
\text { Australasia } \\
\text { North America } \\
\quad \text { (Except United States) } \\
\text { Africa } \\
\text { South America } \\
\text { TOTAL }\end{array}$ & $\begin{array}{r}424 \\
892 \\
307 \\
17 \\
97 \\
29 \\
187 \\
\text { I }, 953\end{array}$ & $\begin{array}{r}271 \\
890 \\
209 \\
13 \\
65 \\
19 \\
89 \\
\text { I , } 556\end{array}$ & $\begin{array}{r}64 \\
100 \\
68 \\
77 \\
67 \\
66 \\
48 \\
80\end{array}$ & $\begin{array}{r}70,480,675 \\
\text { I I I , 47 I, I } 83 \\
22,698,564 \\
\text { I , I } 28,564 \\
5,521,021 \\
\\
\text { I , 289, } 946 \\
2,297,857 \\
2 \text { I } 4,887,810\end{array}$ & $\begin{array}{r}260,076 \\
125,429 \\
108,606 \\
86,813 \\
84,939 \\
67,892 \\
25,819 \\
138,103\end{array}$ \\
\hline
\end{tabular}

TABLE II

Libraries in Universities of the World Reporting More than 500,000 Volumes Each

\begin{tabular}{|c|c|c|}
\hline Institution & Country & Volumes \\
\hline I. Harvard University & United States & $5,500,000$ \\
\hline 2. Yale University & United States & $4,056,276$ \\
\hline 3. Leningrad State University of the Order of Lenin & U. S. S. R. & $3,600, \infty 00$ \\
\hline 4. Stanford University & United States & $2,743,079$ \\
\hline 5. University of California & United States & $2,717,763$ \\
\hline 6. University of Illinois & United States & $2,476,954$ \\
\hline 7. University of Paris (Sorbonne) & France & $2,056,300$ \\
\hline 8. Columbia University & United States & $2, \infty 09,898$ \\
\hline 9. Moscow M. V. Lomonosov State University of the Order of Lenin & U.S. S. R. & $2, \infty, \infty, \infty$ \\
\hline I0. Charles University of Prague & Czechoslovakia & $1,900,000$ \\
\hline I I. University of Oxford & Great Britain & I, 874,000 \\
\hline I2. University of Chicago & United States & I, 844,173 \\
\hline I3. University of Minnesota & United States & $1,600,000$ \\
\hline I4. Kyoto University & Japan & I $, 565,440$ \\
\hline I 5. University of Strasbourg & France & I $, 537,692$ \\
\hline I6. Cornell Úniversity & United States & I, $, 500, \infty 00$ \\
\hline 17. University of Michigan & United States & I $, 454,676$ \\
\hline I8. University of Basel & Switzerland & I $, 359,679$ \\
\hline I9. University of Vienna & Austria & $I, 350,000$ \\
\hline 20. State University of Leiden & Netherlands & I $, 300, \infty 00$ \\
\hline 21. Odessa L. L. Mechnikov State University & U. S. S. R. & $1,300, \infty 00$ \\
\hline 22. University of Toulouse & France & $1,290,376$ \\
\hline 23. Tokyo University & Japan & I, 276,804 \\
\hline 24. Friedrich Wilhelm University of Berlin & Germany & $1,236,017$ \\
\hline 25. Helsinki University & Finland & $1,200,000$ \\
\hline 26. Princeton University & United States & I, 200,000 \\
\hline 27. University of Leipzig & Germany & I $, 200, \infty 00$ \\
\hline 28. University of Heidelberg & Germany & $1,200,000$ \\
\hline 29. University of Oslo & Norway & $1,200, \infty 00$ \\
\hline 30. University of Pennsylvania & United States & I $, 194,808$ \\
\hline 31. University of Warsaw & Poland & I , I 50,000 \\
\hline 32. George August University of Göttingen & Germany & I , I I 5,000 \\
\hline 33. Duke University & United States & $1,040,000$ \\
\hline 34. Northwestern University & United States & $1,031,000$ \\
\hline 35. Friedrich Alexander University of Erlangen & Germany & $1, \infty 00, \infty 00$ \\
\hline 36. Royal University of Upsala & Sweden & $1, \infty 00, \infty 00$ \\
\hline 37. State University at Liege & Belgium & I $, \infty 00, \infty$ \\
\hline 38. University of Bologna & Italy & $1, \infty 00, \infty 00$ \\
\hline 39. University of China & China & $1, \infty 00, \infty 00$ \\
\hline 40. University of Ghent & Belgium & $1, \infty 0, \infty \infty$ \\
\hline 4I. Albert Ludwig University of Freiburg & Germany & 953,785 \\
\hline
\end{tabular}

(Continued on next page)

OCTOBER, 1954 
TABLE II-Continued

\begin{tabular}{|c|c|c|}
\hline Institution & Country & Volumes \\
\hline 42. Brown University & United States & 950,000 \\
\hline 43. University of Texas & United States & $935, \infty 00$ \\
\hline 44. New York University & United States & 925,000 \\
\hline 45. Laval University. & Canada & 919,818 \\
\hline 46. Ohio State University & United States & 910,000 \\
\hline 47. Indiana University & United States & 900,000 \\
\hline 48. Johns Hopkins University & United States & 873, I 16 \\
\hline 49. Rhenish Westphalian Technical University of Aachen & Germany & 828,000 \\
\hline 50. Keiogijuku University & Japan & $800, \infty 00$ \\
\hline 51. Masaryk University of Brno & Czechoslovakia & 800,000 \\
\hline 52. University of Zagreb & Yugoslavia & 800,000 \\
\hline 53. Victor Babes University & Rumania & $800, \infty 00$ \\
\hline 54. University of Toronto & Canada & 791,723 \\
\hline 55. Virginia Poly technic Institute & United States & 784,047 \\
\hline 56. Friedrich Schiller University of Jena & Germany & 782,300 \\
\hline 57. Martin Luther University of Halle-Wittenberg & Germany & 780,000 \\
\hline 58. University of Rome & Italy & 777,622 \\
\hline 59. Ludwig Maximilian University of Munich & Germany & 750,000 \\
\hline 6o. University of Wisconsin & United States & 750,000 \\
\hline 6I. State University of Utrecht & Netherlands & 744,500 \\
\hline 62. University of Washington & United States & 733,429 \\
\hline 63. State College of Washington & United States & 720,000 \\
\hline 64. National Peiping University & China & 713,189 \\
\hline 65. University of Hawaii & United States & 709,479 \\
\hline 66. University of Geneva & Switzerland & 700,000 \\
\hline 67. University of Nancy & France & 700,000 \\
\hline 68. University of Cincinnati & United States & $690, \infty 00$ \\
\hline 69. Dartmouth College & United States & 679,785 \\
\hline 70. Western Reserve University & United States & 664,079 \\
\hline 71. State University of Iowa & United States & 646,623 \\
\hline 72. University of Lyon & France & 635,000 \\
\hline 73. University of Virginia & United States & 630,633 \\
\hline 74. University of Lille & France & 630,000 \\
\hline 75. University of Missouri & United States & 625,000 \\
\hline 76. Eberhard Karls University at Tübingen & Germany & $619, \infty 00$ \\
\hline 77. University of Pittsburgh & United States & $617, \infty 00$ \\
\hline 78. Rutgers University & United States & 616,180 \\
\hline 79. University of Southern California & United States & 605,996 \\
\hline 80. Higher Normal School & France & 600,000 \\
\hline 81. Johann Wolfgang Goethe University of Frankfort & Germany & $600, \infty 00$ \\
\hline 82. University of Hamburg & Germany & $600, \infty 00$ \\
\hline 83. University of Oklahoma & United States & 591,000 \\
\hline 84. Peabody-Vanderbilt-Scarritt & United States & 589,765 \\
\hline 85. Rhenish Frederick William University of Bonn & Germany & 585,000 \\
\hline 86. University of North Carolina & United States & 581,682 \\
\hline 87. University of Cambridge & Great Britain & 574,200 \\
\hline 88. University of Montpellier & France & 573,401 \\
\hline 89. University of Oregon & United States & 553,9 I 8 \\
\hline 90. Cuza-Voda University of Jassy & Rumania & $550, \infty 00$ \\
\hline 9I. Saint John's University & China & 542,253 \\
\hline 92. Royal Conservatory of Music & Sweden & 540,000 \\
\hline 93. University of Pavia & Italy & 537,000 \\
\hline 94. Louisiana State University & United States & $53^{2}, 4^{85}$ \\
\hline 95. University of Rochester & United States & 53 I , I I 9 \\
\hline 96. University of Kentucky & United States & 530,000 \\
\hline 97. Washington University & United States & 527,346 \\
\hline 98. University of Edinburgh & Great Britain & 522,000 \\
\hline 99. Catholic University of Louvain & Belgium & 500,000 \\
\hline Ioo. Hebrew University & Israel & 500,000 \\
\hline IOI. Kiev T. G. Shevchenko State University & U. S. S. R. & $500, \infty 00$ \\
\hline 102. University of Caglieri & Italy & 500,000 \\
\hline I03. University of Dublin & Ireland & 500,000 \\
\hline I04. University of Gothenburg & Sweden & 500,000 \\
\hline
\end{tabular}


wide data on educational factors. Table I summarizes the significant data for 1556 university and college libraries in $7 \mathrm{I}$ countries. It may be noted that for the world as a whole four-fifths of the 1953 institutions for which institutional exhibits are given reported number of volumes in their libraries. The proportion reporting is approximately two-thirds or higher for all except South America where slightly less than half of the institutions gave this information.

Table II lists the IO4 institutions reported as having the largest university libraries-all with 500,000 volumes or more. Only nine are reported with more than two million volumes each and six of these are in the United States. Harvard University stands out preeminently as having the world's largest university library.

In the class from one to two million volumes each are $3 \mathrm{I}$ institutions, of which eight are in the United States. In the class of less than a million but more than a half million are found 64 institutions, of which 28 are in the United States.
Number of institutions classified by countries in the entire list of $\mathrm{IO}_{4}$ are as follows: United States, 42 ; Germany, I4; France, 8; Italy and U.S.S.R., 4 each; Belgium, China, Great Britain, Japan, and Sweden, 3 each; Canada, Czechoslovakia, Netherlands, Rumania, and Switzerland, 2 each; and Austria, Finland, Ireland, Israel, Norway, Poland, and Yugoslavia, I each.

All of the universities reporting libraries of more than 500,000 volumes each are in Europe, Asia, and North America. The largest university library reported in Africa is that of Fouad I University (renamed the University of Cairo since the abdication of King Farouk) with 340,526 volumes. The largest reported in South America is that of the University of Chile with 300,000 volumes. The largest reported in Australasia is that of the University of Sydney with 298,973 volumes.

Table III gives a classification of the I 556 university libraries for which data are available according to number of volumes reported. It may be noted that more

TABLE III

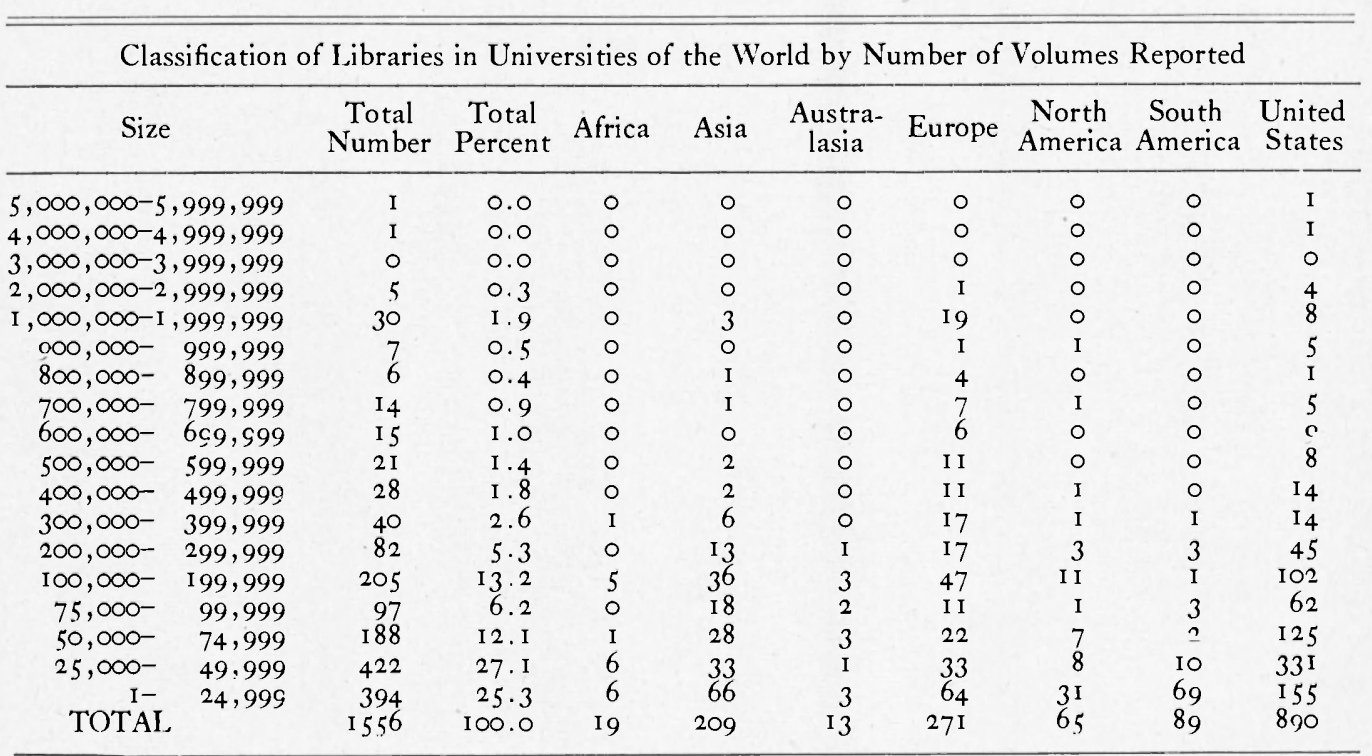

OCTOBER, 1954 
than half $(52.4 \%)$ of the libraries have less than 50,000 volumes each; that less than one-sixth of them have more than I00,000 volumes each. Only 6\% have 500,000 volumes or more as already listed individually in Table II.

Table IV presents information on the average number of volumes in the higher educational institutions of each of the $7 \mathrm{I}$ countries covered in this article. The first two columns give the number of institutions in each country for which exhibits were available and the number of these which reported number of volumes in their libraries. For 25 of these countries, mostly the smaller ones, reports of volumes are complete for all of the reporting institutions in the country. The largest of the countries for which this is true is Japan where library data were given by all of the 55 reporting universities. On the other hand there are only four countries for which the average is based upon less than half of the reporting institutions in those countries. It will be noted that all of the larger averages are for countries in Europe.

TABLE IV

Average Number of Volumes Reported in University Libraries in Various Countries of the World

\begin{tabular}{|c|c|c|c|}
\hline Country & $\begin{array}{l}\text { Number of } \\
\text { Institutions } \\
\text { Having } \\
\text { Exhibits }\end{array}$ & $\begin{array}{c}\text { Number of Institu- } \\
\text { tions Reporting } \\
\text { Library } \\
\text { Information }\end{array}$ & $\begin{array}{l}\text { Average Number } \\
\text { of Volumes in } \\
\text { Reporting } \\
\text { Libraries }\end{array}$ \\
\hline \multirow{5}{*}{$\begin{array}{l}\text { I. Yugoslavia } \\
\text { 2. Switzerland } \\
\text { 3. Rumania } \\
\text { 4. Czechoslovakia } \\
\text { 5. Netherlands }\end{array}$} & 2 & 2 & \multirow{5}{*}{$\begin{array}{l}605, \\
594, \\
5 \circ 3, \\
370, \\
368,\end{array}$} \\
\hline & IO & 4 & \\
\hline & 4 & 3 & \\
\hline & I 2 & 9 & \\
\hline & IO & 9 & \\
\hline \multirow{5}{*}{$\begin{array}{l}\text { 6. Germany } \\
\text { 7. Finland } \\
\text { 8. Great Britain and Northern Ireland } \\
\text { 9. France } \\
\text { I0. Israel }\end{array}$} & 59 & 52 & 301,502 \\
\hline & & 8 & 205,519 \\
\hline & 29 & 25 & $29 \mathrm{I}, 7 \mathrm{II}$ \\
\hline & 62 & 38 & 288,465 \\
\hline & 2 & 2 & $260, \infty 00$ \\
\hline \multirow{5}{*}{$\begin{array}{l}\text { I 1. Norway } \\
\text { 1 2. Austria } \\
\text { 13. Ireland } \\
\text { I 4. Italy } \\
\text { 15. Argentina }\end{array}$} & 7 & 7 & 252,777 \\
\hline & 13 & 13 & 234,345 \\
\hline & 6 & 5 & 217,000 \\
\hline & 37 & 26 & $20 \mathrm{I}, 42 \mathrm{I}$ \\
\hline & 6 & 3 & 196,544 \\
\hline \multirow{5}{*}{$\begin{array}{l}\text { 16. Sweden } \\
\text { I7. Belgium } \\
\text { I8. Japan } \\
\text { I9. Hungary } \\
\text { 20. Spain }\end{array}$} & 16 & I 3 & 196,338 \\
\hline & 19 & 17 & I 92, I 94 \\
\hline & 55 & 55 & 189,559 \\
\hline & 6 & 3 & 177,528 \\
\hline & I6 & 8 & 165,519 \\
\hline \multirow{5}{*}{$\begin{array}{l}\text { 21. Lebanon } \\
\text { 22. Canada } \\
\text { 23. Poland } \\
\text { 24. Chile } \\
\text { 25. Egypt }\end{array}$} & 3 & 3 & 135,187 \\
\hline & 39 & 33 & I 35, I 78 \\
\hline & 16 & I3 & I 29,583 \\
\hline & 6 & 5 & $\mathrm{I} 28,8 \mathrm{I}$ I \\
\hline & 5 & 4 & I 26, I 32 \\
\hline \multirow{5}{*}{$\begin{array}{l}\text { 26. United States } \\
\text { 27. Pakistan } \\
\text { 28. Australia } \\
\text { 29. China } \\
\text { 30. Hong Kong }\end{array}$} & 892 & 890 & I 25,429 \\
\hline & 3 & 2 & I I 8,430 \\
\hline & 9 & 8 & 106,787 \\
\hline & $\begin{array}{r}87 \\
\text { I }\end{array}$ & $\begin{array}{r}78 \\
\text { I }\end{array}$ & IOI , I 77 \\
\hline & & & 98,690 \\
\hline \multirow{2}{*}{$\begin{array}{l}\text { 31. Union of South Africa } \\
\text { 32. Portugal }\end{array}$} & Io & 9 & $76,88 \circ$ \\
\hline & 6 & 3 & 76,314 \\
\hline
\end{tabular}


TABLE IV-Continued

\begin{tabular}{|c|c|c|c|}
\hline Country & $\begin{array}{l}\text { Number of } \\
\text { Institutions } \\
\text { Having } \\
\text { Exhibits }\end{array}$ & $\begin{array}{c}\text { Number of Institu- } \\
\text { tions Reporting } \\
\text { Library } \\
\text { Information }\end{array}$ & $\begin{array}{c}\text { Average Number } \\
\text { of Volumes in } \\
\text { Reporting } \\
\text { Libraries }\end{array}$ \\
\hline $\begin{array}{l}\text { 33. Burma } \\
\text { 34. India } \\
\text { 35. Greece }\end{array}$ & $\begin{array}{r}\text { I } \\
33 \\
\text { I I }\end{array}$ & $\begin{array}{r}\text { I } \\
27 \\
5\end{array}$ & $\begin{array}{l}70,000 \\
64,209 \\
61,696\end{array}$ \\
\hline $\begin{array}{l}\text { 36. Dominican Republic } \\
\text { 37. Korea } \\
\text { 38. New Zealand } \\
\text { 39. Denmark } \\
\text { 40. Iceland }\end{array}$ & $\begin{array}{r}\text { I } \\
\text { I } 2 \\
7 \\
\text { IO } \\
\text { I }\end{array}$ & $\begin{array}{r}\text { I } \\
\text { I I } \\
5 \\
7 \\
\text { I }\end{array}$ & $\begin{array}{l}60, \infty 00 \\
59,674 \\
54,854 \\
52,359 \\
51, \infty 00\end{array}$ \\
\hline $\begin{array}{l}\text { 41. Ceylon } \\
\text { 42. El Salvador } \\
\text { 43. Mexico } \\
\text { 44. Malaya and Singapore } \\
\text { 45. Panama }\end{array}$ & $\begin{array}{r}2 \\
1 \\
30 \\
3 \\
1\end{array}$ & $\begin{array}{r}\mathrm{I} \\
\mathrm{I} \\
\mathrm{I} 7 \\
\mathrm{I} \\
\mathrm{I}\end{array}$ & $\begin{array}{l}50,000 \\
50,000 \\
43,843 \\
40,000 \\
40, \infty 00\end{array}$ \\
\hline $\begin{array}{l}\text { 46. Philippines } \\
\text { 47. Peru } \\
\text { 48. Colombia } \\
\text { 49. Turkey } \\
\text { 50. Cuba }\end{array}$ & $\begin{array}{r}\text { I } 4 \\
\text { I } \\
\text { I } 2 \\
\text { I0 } \\
5\end{array}$ & $\begin{array}{r}\text { I I } \\
9 \\
8 \\
6 \\
5\end{array}$ & $\begin{array}{l}29,735 \\
29,203 \\
27,775 \\
26,372 \\
26,000\end{array}$ \\
\hline $\begin{array}{l}\text { 51. British West Africa } \\
\text { 52. Bulgaria } \\
\text { 53. Ecuador } \\
\text { 54. Bolivia } \\
\text { 55. Syria }\end{array}$ & $\begin{array}{l}2 \\
3 \\
5 \\
8 \\
I\end{array}$ & $\begin{array}{l}2 \\
\mathrm{I} \\
4 \\
6 \\
\mathrm{I}\end{array}$ & $\begin{array}{l}24,000 \\
20,000 \\
18,947 \\
17,013 \\
17,000\end{array}$ \\
\hline $\begin{array}{l}\text { 56. Anglo-Egyptian Sudan } \\
\text { 57. Siam (Thailand) } \\
\text { 58. British East Africa } \\
\text { 59. Haiti } \\
\text { 60. Malta }\end{array}$ & $\begin{array}{l}\text { I } \\
4 \\
\text { I } \\
\text { I } \\
\text { I }\end{array}$ & $\begin{array}{l}\text { I } \\
4 \\
\text { I } \\
\text { I } \\
\text { I }\end{array}$ & $\begin{array}{l}\text { I } 5,000 \\
\text { I } 4,109 \\
\text { I } 2,500 \\
\text { I0, } 000 \\
\text { I0, } 000\end{array}$ \\
\hline $\begin{array}{l}\text { 61. Paraguay } \\
\text { 62. Costa Rica } \\
\text { 63. Mauritius } \\
\text { 64. Brazil } \\
\text { 65. Venezuela }\end{array}$ & $\begin{array}{r}3 \\
2 \\
I \\
64 \\
4\end{array}$ & $\begin{array}{r}\text { I } \\
2 \\
\mathrm{I} \\
52 \\
\mathrm{I}\end{array}$ & $\begin{array}{l}9,278 \\
8,500 \\
8,000 \\
7,425 \\
6,000\end{array}$ \\
\hline $\begin{array}{l}\text { 66. Afghanistan } \\
67 . \text { Iran } \\
\text { 68. Honduras } \\
\text { 69. Indo-China } \\
\text { 70. Nicaragua } \\
\text { 71. Iraq }\end{array}$ & $\begin{array}{l}\text { I } \\
2 \\
\text { I } \\
\text { I } \\
3 \\
3\end{array}$ & $\begin{array}{l}\text { I } \\
\text { I } \\
\text { I } \\
\text { I } \\
3 \\
2\end{array}$ & $\begin{array}{r}4, \infty 00 \\
3, \infty 00 \\
2,328 \\
2,250 \\
1,833 \\
6 \mathrm{I} 7\end{array}$ \\
\hline
\end{tabular}

\section{Please Note}

The index to volume 15 of c\&RL will appear in The January, 1955 issue.

Title pages for C\&RL are no longer being published. The last one issued covered volume I3 ( 1952 ). 